\title{
Sedation During Oral Treatment in Special Care Patients: An Integrative Review
}

\section{ISSN: 2637-7764}

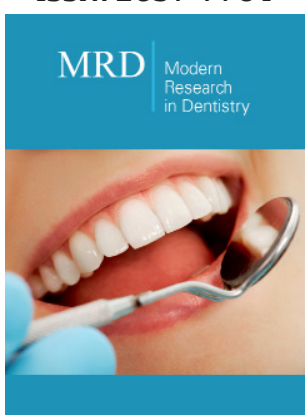

*Corresponding author: Alessandra Rodrigues de Camargo, Department of Dentistry, Health Science Center, Federal University of Santa Catarina, 88040-370, Florianópolis, Brazil

\section{Submission: 眥June 24, 2020}

Published: 制September 23, 2020

Volume 5 - Issue 4

How to cite this article: Sinioly Cristina Machado, Bruna de Oliveira Rech, Beatriz Álvares Cabral de Barros, Rubens Rodrigues Filho, Alessandra Rodrigues de Camargo. Sedation During Oral Treatment in Special Care Patients: An Integrative Review. Mod Res Dent. 5(4). MRD. 000617. 2020.

DOI: 10.31031/MRD.2020.05.000617

Copyright@ Alessandra Rodrigues de Camargo, This article is distributed under the terms of the Creative Commons Attribution 4.0 International License, which permits unrestricted use and redistribution provided that the original author and source are credited.

\section{Sinioly Cristina Machado ${ }^{1}$, Bruna de Oliveira Rech ${ }^{2}$, Beatriz Álvares Cabral de Barros $^{3}$, Rubens Rodrigues Filho ${ }^{4}$ and Alessandra Rodrigues de Camargo ${ }^{5 *}$}

${ }^{1}$ Graduate student, Departament of Dentistry, School of Dentristry, University Federal of Santa Catarina, Florianópolis, Brazil

${ }^{2}$ Post graduate student, Department of Stomatology, School of Dentistry, University of São Paulo, São Paulo, Brazil

${ }^{3}$ Department of Dentistry, School of Dentistry, Federal University of Santa Catarina, Florianópolis, Brazil

${ }^{4}$ School of Dentistry, Federal University of Santa Catarina, Florianópolis, Brazil

${ }^{5}$ Department of Stomatology, School of Dentistry, Federal University of Santa Catarina, Florianópolis, Brazil

\begin{abstract}
Background: Dental treatment must be effective with acceptance and safety for patients with special needs, with this option, the choosing of sedation through the technique and your sedative drug, it's the way where treatment should be based. So, it's important to be aware of what type of sedation we can use to make dental procedures feasible for people with disabilities.
\end{abstract}

Material and method: An integrative review of literature, where research was conducted in the electronic databases: LILACS, PubMed, Scopus, Embase and Scielo. Held on May 29, 2020. Research articles in the area of patients with special needs (people with disabilities) from the last seven years who evaluated different sedation techniques. Excluding literature reviews, personal opinions and case reports.

Result: In the initial research, 315 articles were found, coming from the five electronic databases. Eliminating duplicates, 189 articles remained, after reading the titles and abstracts 11 articles were selected, 2 articles were excluded, finalizing with 9 articles about sedation in patients with disabilities.

Conclusion: The dentist can make use of the sedation technique to provide and enable the treatment of patients with disabilities, when cooperation is not enough, or the treatment brings insecurity or discomfort to the patient.

Keywords: Patients with special needs;Conscious sedation;Sedative drugs

\section{Introduction}

Dental care in patients with special needs has always been challenging. According to the Dental Accreditation Commission (CODA), patients with special needs are defined as any individual who has a medical, psychological, physical or social condition, who needs individualized dental treatment [1]. Among these, neurological motor disorders such as Down Syndrome, Cerebral Palsy or even patients diagnosed with Autistic Spectrum Disorder (ASD) are often not able to have emotional control or complete intellectual development, and their ability to understand and cooperate may be affected by undergoing dental treatment $[2,3]$. Most of the time conditioning is the first method of choice for care, but it is not always enough. In these cases we use conscious sedation, a technique that can be performed with one or a combination of more medications that establish a state of depression of the central nervous system, effectively and safely whether performed by oral, nasal, intramuscular, intravenous (IV), subcutaneous or inhaled [4]. Thus, it allows the necessary dental treatment to be performed in a less traumatic way for the patient and more comfortable to the professional [5].

The use of conscious sedation in Dentistry is widely discussed with clinical guidelines and standards for its practice [6]. However, the biggest problem related to this type of sedation in 
a non-hospital environment is the rapid progression that can occur with a decrease in the level of sedation that can lead to unintentional loss of consciousness [7]. For this reason, a thorough airway assessment, appropriate fasting, pharmacodynamic understanding, wide safety margin of the drug of choice and emergency equipment readiness is necessary [8]. On the other hand, when well applied and indicated, the technique has the importance of enabling a successful dental treatment, avoiding the discomfort, and suffering of the patient [9]. A dental treatment that unites effectiveness, acceptance and safety for patients with special needs is essential. For this reason, the choice of sedation technique and the drug of choice are the basis for an equal and safe treatment. Therefore, the objective of this integrative review is to know, what type of sedation can we use in dental treatments for people with disabilities.

\section{Methods}

\section{Eligibility criteria}

This integrative review was written based on the items of Systematic Reviews and Meta-Analysis PRISMA Checklist. As inclusion criteria, studies were selected in the area of patients with special needs (people with disabilities), these being clinical research studies from the last seven years. As exclusion criteria, review works, personal opinions and clinical cases were excluded.

\section{Information sources}

The electronic search was performed in the following databases: LILACS, PubMed, Scopus, Embase and SciELO (more information about the search strategies is provided in Appendix 1). The search in all databases was carried out on May 29, 2020, without language restriction.

\section{Appendix 1: Search.}

\begin{tabular}{|c|c|}
\hline Database & $\begin{array}{c}\text { Search } \\
\text { (May 29, 2020) }\end{array}$ \\
\hline LILACS & 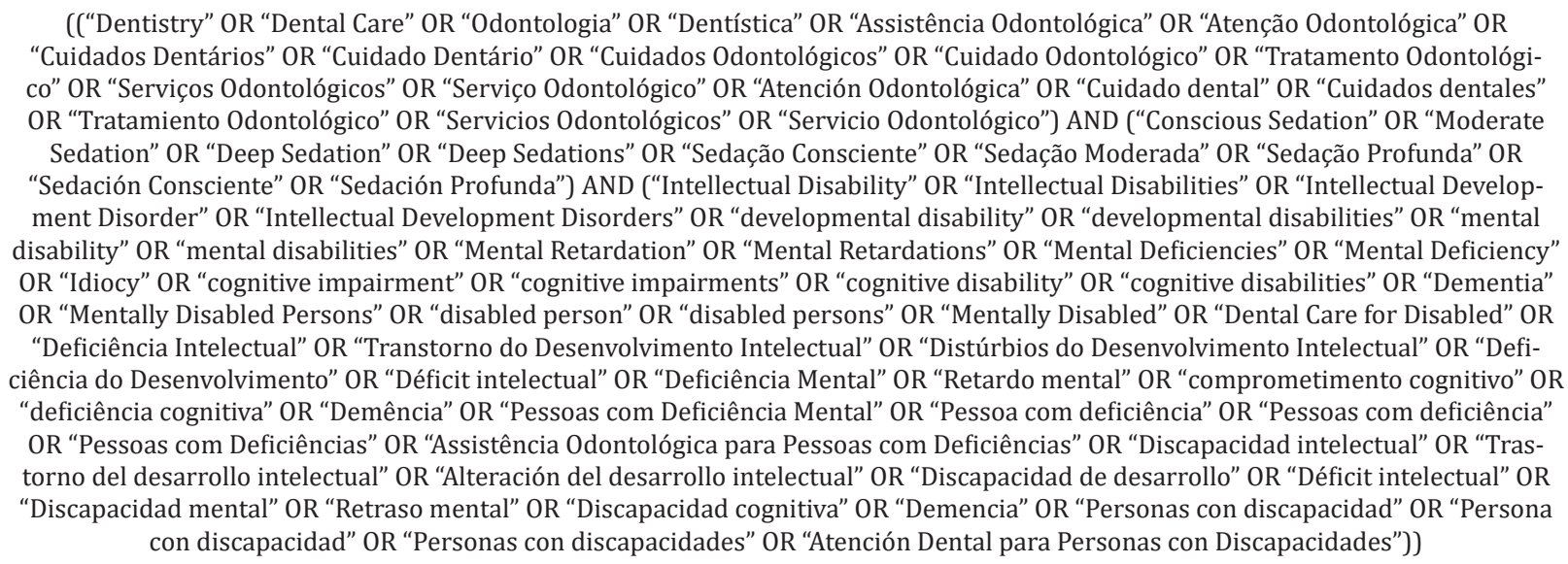 \\
\hline PubMed & 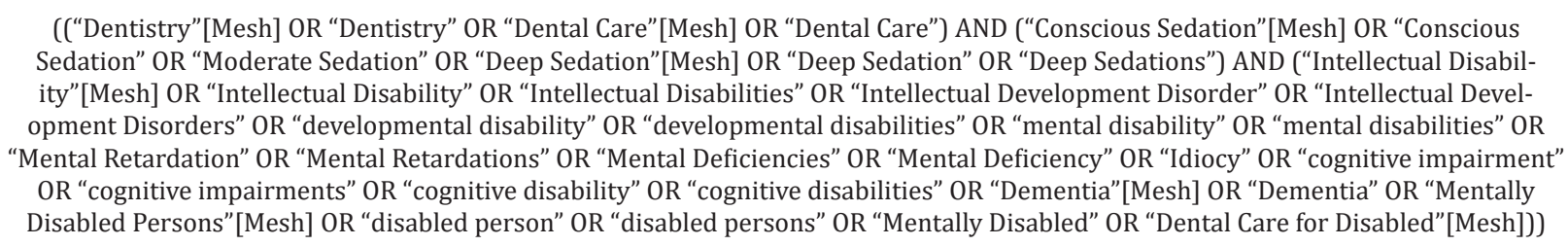 \\
\hline Scopus & 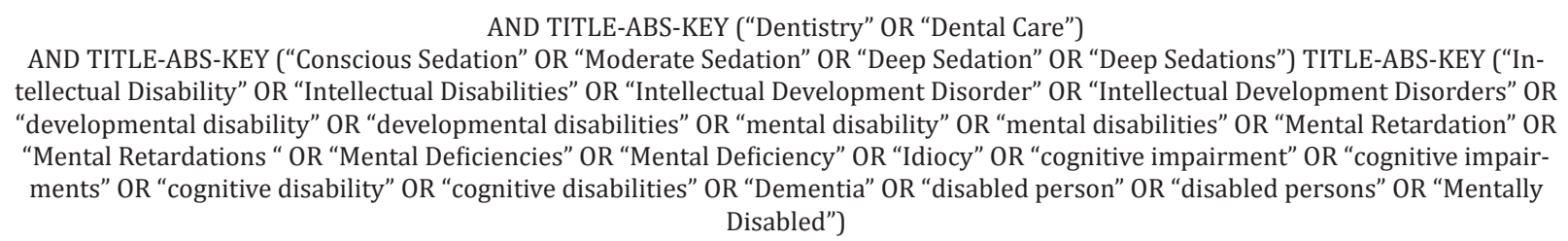 \\
\hline
\end{tabular}




\begin{tabular}{|c|c|}
\hline Embase & $\begin{array}{c}\text { ('conscious sedation'/exp OR 'conscious sedation' OR 'moderate sedation'/exp OR 'moderate sedation' OR 'deep sedation'/exp OR 'deep } \\
\text { sedation' OR 'deep sedations') AND ('intellectual disability'/exp OR 'intellectual disability' OR 'intellectual disabilities' /exp OR 'in- } \\
\text { tellectual disabilities' OR 'intellectual development disorder' OR 'intellectual development disorders' OR 'developmental disabili- } \\
\text { ty' OR 'developmental disabilities'/exp OR 'developmental disabilities' OR 'mental disability'/exp OR 'mental disability' OR 'mental } \\
\text { disabilities' OR 'mental retardation'/exp OR 'mental retardation' OR 'mental retardations' OR 'mental deficiencies' OR 'mental defi- } \\
\text { ciency'/exp OR 'mental deficiency' OR 'idiocy'/exp OR 'idiocy' OR 'cognitive impairment'/exp OR 'cognitive impairment' OR 'cognitive } \\
\text { impairments' OR 'cognitive disability'/exp OR 'cognitive disability' OR 'cognitive disabilities' OR 'dementia'/exp OR 'dementia' OR 'dis- } \\
\text { abled person'/exp OR ‘disabled person' OR 'disabled persons'/exp OR 'disabled persons' OR 'mentally disabled') AND ('dentistry'/exp } \\
\text { OR 'dentistry' OR 'dental care'/exp OR 'dental care') }\end{array}$ \\
\hline Scielo & 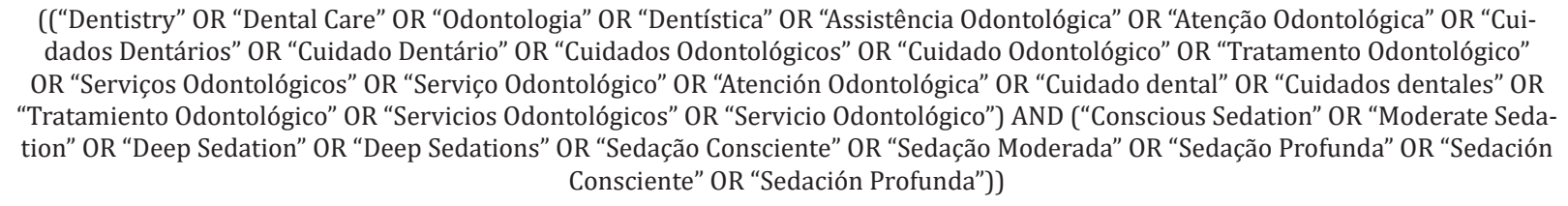 \\
\hline ProQuest & 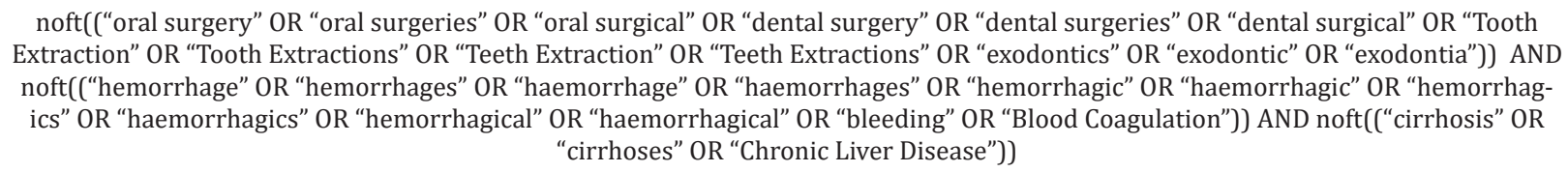 \\
\hline
\end{tabular}

\section{Study selection}

The selection of studies was carried out in three phases. The first with the help of reference management software (EndNote ${ }^{\circledR}$ X7 Thomson Reuters, Philadelphia, PA) used to collect references and exclude duplicates. In the second phase, two reviewers (BOR and SCM) independently reviewed the titles and abstracts of all articles selected in the search. In this phase, articles that clearly did not fit the inclusion criteria or that fit any of the exclusion criteria were excluded. In the third phase, the remaining articles were read in full and evaluated based on the same eligibility criteria.

\section{Data collection process and data items}

Initially an author (SCM) collected the necessary information from the selected studies. Shortly after the second author (BOR) confirmed the integrity of the information collected. For each of the selected studies, we collect the following data: authors, year of publication, country, sample number, sample (characteristics), age of participants, type of sedation, route administered, results and conclusions.

\section{Result}

\section{Study selection}

During the initial search, 315 citations were identified in five electronic databases (PubMed, Scopus, Embase, LILACS, and Scielo). After the elimination of duplicate papers, 189 remained. Then, after reading titles and abstracts, eleven articles were considered potentially useful and selected for evaluation in phase 2 , in this phase two articles found were excluded, totalling nine studies. No studies were selected from Pro Quest, Open Grey or from referral by experts. Therefore, nine articles were selected for data collection in order to answer the research questions. Figure 1 illustrates the process of identifying and selecting studies.

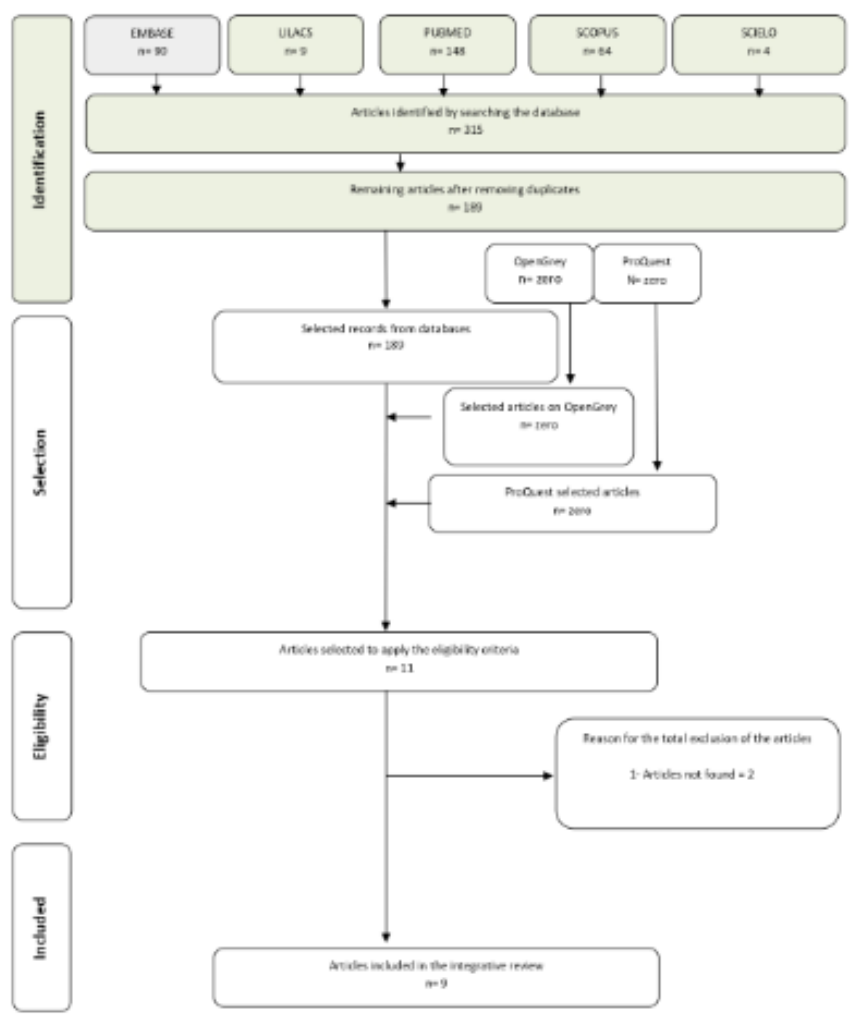

Figure 1: Flowchart of bibliographic research and selection criteria. 


\section{Study characteristics}

Table 1: Summary of the descriptive characteristics of the articles included.

\begin{tabular}{|c|c|c|c|c|c|c|c|c|}
\hline $\begin{array}{l}\text { Author } \\
\text { / Year }\end{array}$ & Country & $\begin{array}{l}\text { Sample } \\
\text { Number }\end{array}$ & $\begin{array}{c}\text { Sample } \\
\text { (Characte- } \\
\text { ristic) }\end{array}$ & $\begin{array}{l}\text { Middle } \\
\text { Ages }\end{array}$ & $\begin{array}{l}\text { Type of } \\
\text { Sedation }\end{array}$ & $\begin{array}{c}\text { Route } \\
\text { Administe- } \\
\text { red }\end{array}$ & Results & Conclusion \\
\hline $\begin{array}{l}\text { Mat- } \\
\text { suki et } \\
\text { al. [10] }\end{array}$ & Japan & 507 & $\begin{array}{l}\text { Cerebral } \\
\text { palsy, Mental } \\
\text { retardation, } \\
\text { Mental } \\
\text { disorder. }\end{array}$ & 38,63 & $\begin{array}{l}\text { Midazolam } \\
\text { and Pro- } \\
\text { pofol }\end{array}$ & $\begin{array}{c}\text { Intravenous } \\
\text { Sedation }\end{array}$ & $\begin{array}{c}\text { - Midazolam-Propofol } \\
\text { 67.3\% } \\
\text {-Midazolam } 16.8 \% \\
\text { - Propofol } 13.8 \% \\
\text { - intraoperative respiratory } \\
\text { depression and reduction in } \\
\text { Sp02, occurred in patients } \\
\text { who received deep sedation. }\end{array}$ & $\begin{array}{l}\text { There are several factors that } \\
\text { involve the choice of sedative } \\
\text { agents for intravenous sedation, } \\
\text { therefore, the safety and comfort } \\
\text { of the patient in dental treat- } \\
\text { ments must be considered. }\end{array}$ \\
\hline $\begin{array}{c}\text { Alkan } \\
\text { et al. } \\
2015\end{array}$ & Turkey & 214 & $\begin{array}{c}\text { Down } \\
\text { syndrome, } \\
\text { Cornelia de } \\
\text { Lange syn- } \\
\text { drome, Van } \\
\text { der Knaap } \\
\text { disease, } \\
\text { Fragile X } \\
\text { syndrome, } \\
\text { Cerebral pal- } \\
\text { sy, Autism, } \\
\text { Williams } \\
\text { syndrome, }\end{array}$ & 22,49 & $\begin{array}{l}\text { Midazolam, } \\
\text { Ketamine, } \\
\text { Propofol, } \\
\text { Sevoflura- } \\
\text { ne, Nitrous } \\
\text { Oxide, } \\
\text { Fentanyl, }\end{array}$ & $\begin{array}{l}\text {-Intra- } \\
\text { venous } \\
\text { sedation } \\
\text {-Inhalation } \\
\text { sedation } \\
\text { - Combina- } \\
\text { tion of both }\end{array}$ & $\begin{array}{l}\text { - } 6.5 \% \text { of participants sub- } \\
\text { mitted to minimal sedation, } \\
35 \% \text { moderate and } 58.4 \\
\text { profound. } \\
\text { - } 3.7 \% \text { of participants } \\
\text { experienced nausea and } \\
\text { vomiting - } 2 \text { participants } \\
\text { developed bronchospasm. } \\
\text { - } 2 \text { participants respiratory } \\
\text { depression and } 1 \text { agitation, } \\
\text { bradycardia. }\end{array}$ & $\begin{array}{l}\text { Sedation can be performed } \\
\text { safely, with the choice of the ap- } \\
\text { propriate medication and using } \\
\text { methods without depressing } \\
\text { breathing and reflexes. }\end{array}$ \\
\hline $\begin{array}{l}\text { Sugi- } \\
\text { mura } \\
\text { et al. } \\
{[11]}\end{array}$ & Japan & 25 & Insanity & 79,9 & Propofol & $\begin{array}{c}\text { Intravenous } \\
\text { Sedation }\end{array}$ & $\begin{array}{c}\text { - } 46.2 \% \text { circulatory } \\
\text { complications and } 52.3 \% \\
\text { respiratory. } \\
\text { - Bradycardia in } 13.8 \% \text { and } \\
\text { hypotension in } 12.3 \% \\
\text { - Cough attacks in } 41.5 \% \\
\text { and snoring in } 16.9 \% .\end{array}$ & $\begin{array}{l}\text { Dental treatments can be per- } \\
\text { formed without problems with } \\
\text { sedation by intravenous route, } \\
\text { however paying attention to } \\
\text { the aspiration of fluids, airway } \\
\text { obstruction and respiratory } \\
\text { inhibition. }\end{array}$ \\
\hline $\begin{array}{l}\text { Mori- } \\
\text { moto } \\
\text { et al. } \\
{[12]}\end{array}$ & Japan & 43 & $\begin{array}{l}\text { Intellectual } \\
\text { disability, } \\
\text { autism, } \\
\text { epilepsy, } \\
\text { cerebral } \\
\text { palsy, Down } \\
\text { syndrome, } \\
\text { hearing } \\
\text { impairment } \\
\text { and Cornelia } \\
\text { de Lange } \\
\text { syndrome. }\end{array}$ & 18 & $\begin{array}{c}\text { Midazolam } \\
\text { and Pro- } \\
\text { pofol }\end{array}$ & $\begin{array}{l}\text { Intravenous } \\
\text { Sedation } \\
\text { (IVS) and } \\
\text { Intravenous } \\
\text { Sedation } \\
\text { with airway } \\
\text { and suction } \\
\text { tube (IV- } \\
\text { SAS) }\end{array}$ & $\begin{array}{c}\text { - } 44 \% \text { in IVSAS and } 81.8 \% \text { in } \\
\text { IVS, had a cough reflex. } \\
\text { - } 28 \% \text { in IVSAS and } 72.2 \% \\
\text { in IVS, had spontaneous } \\
\text { movements. } \\
\text { - Regarding the quality of } \\
\text { sedation, there was a lower } \\
\text { incidence of these events, } \\
\text { and a higher quality of seda- } \\
\text { tion in IVSAS. }\end{array}$ & $\begin{array}{l}\text { Participants with moderate or } \\
\text { severe disabilities, intravenous } \\
\text { sedation using the nasal airway, } \\
\text { suction tube and oxygen tube } \\
\text { are considered to improve the } \\
\text { safety of sedation throughout } \\
\text { dental treatment. }\end{array}$ \\
\hline $\begin{array}{c}\text { Rignell } \\
\text { et al } \\
{[13]}\end{array}$ & Sweden & 61 & $\begin{array}{l}\text { Large neu- } \\
\text { rocognitive } \\
\text { disorder. }\end{array}$ & 80 & $\begin{array}{l}\text { Midazo- } \\
\text { lam } 0.1 \text { to } \\
0.2 \mathrm{mg} / \mathrm{kg}\end{array}$ & $\begin{array}{l}\text { Oral Seda- } \\
\text { tion }\end{array}$ & $\begin{array}{c}\text { - } 44 \% \text { of participants with- } \\
\text { out cooperation problems } \\
\text { when sedated. } \\
\text { - } 43 \% \text { of participants treat- } \\
\text { ed with minor adaptations } \\
\text { - Rare unfavorable side } \\
\text { effects. }\end{array}$ & $\begin{array}{c}\text { Oral sedation with Midazolam } \\
\text { seems to be effective and safe } \\
\text { in dental treatments for people } \\
\text { with major neurocognitive } \\
\text { disorders. }\end{array}$ \\
\hline $\begin{array}{l}\text { Her- } \\
\text { manus } \\
\text { H. B. } \\
\text { Vaes- } \\
\text { sen et } \\
\text { al [14] }\end{array}$ & $\begin{array}{l}\text { Nether- } \\
\text { lands }\end{array}$ & 124 & $\begin{array}{l}\text { Intellectual } \\
\text { disability }\end{array}$ & $\begin{array}{l}\text { maior } \\
\text { de } 18\end{array}$ & Propofol & $\begin{array}{l}\text { Intravenous } \\
\text { sedation }\end{array}$ & $\begin{array}{c}\text { - 18.5\% participants pre- } \\
\text { medicated with diazepam } \\
\text { and } 5.6 \% \text { with Oxazepam } \\
\text { (v.o). } \\
\text { - Bradicardia in } 5.6 \% \text { of } \\
\text { cases, } 3.2 \% \text { tachycardia and } \\
0.8 \% \text { hypertension } \\
\text { - Chin lift in } 1.6 \% \text { and verbal } \\
\text { stimulation in } 0.8 \% \text {, were } \\
\text { necessary due to airway } \\
\text { obstruction. }\end{array}$ & $\begin{array}{c}\text { Sedation with Propofol was } \\
\text { effective for dental treatment } \\
\text { and resulted in sufficient levels } \\
\text { of sedation, without compli- } \\
\text { cations and safely in the office } \\
\text { by sedation professionals with } \\
\text { experience and training with } \\
\text { Propofol and participants with } \\
\text { disabilities. }\end{array}$ \\
\hline
\end{tabular}




\begin{tabular}{|c|c|c|c|c|c|c|c|c|}
\hline $\begin{array}{l}\text { Ferrary } \\
\text { et al. } \\
\text { [15] }\end{array}$ & $\begin{array}{l}\text { Argen- } \\
\text { tina }\end{array}$ & 29 & $\begin{array}{l}\text { Down's } \\
\text { syndrome }\end{array}$ & 31,5 & $\begin{array}{c}\text { Midazolam } \\
15 \mathrm{mg} \text { or } \\
30 \mathrm{mg}\end{array}$ & $\begin{array}{l}\text { Oral Seda- } \\
\text { tion }\end{array}$ & $\begin{array}{l}\text { - 71.4\% - } 15 \mathrm{mg} \text { - Houpt } \\
\text { scale of } 4 / 5 . \\
\text { - 93.33\% - 30mg - } 5 / 6 \\
\text { Houpt scale. } \\
\text { - No adverse effects among } \\
\text { participants. }\end{array}$ & $\begin{array}{l}\text { Psychoprophylaxis combined } \\
\text { with conscious oral sedation } \\
\text { has proven to be a good strategy } \\
\text { for participants with Down } \\
\text { Syndrome to have quality dental } \\
\text { treatment. }\end{array}$ \\
\hline $\begin{array}{l}\text { Pic- } \\
\text { ciani et } \\
\text { al. [16] }\end{array}$ & Brazil & 26 & $\begin{array}{l}\text { Autism, } \\
\text { Intellectual } \\
\text { Disability } \\
\text { and Down } \\
\text { Syndrome }\end{array}$ & 18 & $\begin{array}{c}\text { Midazolam } \\
\text { de } 7,5 \text { or } \\
15 \mathrm{mg}\end{array}$ & $\begin{array}{l}\text { Oral Seda- } \\
\text { tion }\end{array}$ & $\begin{array}{l}\text { - 83\% sedation proved to be } \\
\text { safe and effective. } \\
\text {-There was a statistically } \\
\text { significant reduction in the } \\
\text { parameters of systolic and } \\
\text { diastolic blood pressure } \\
\text { in the transoperative and } \\
\text { postoperative periods, when } \\
\text { compared to the preopera- } \\
\text { tive and a 6bpm reduction } \\
\text { in heart rate on average. }\end{array}$ & $\begin{array}{l}\text { Benzodiazepine sedation is safe } \\
\text { and effective for participants } \\
\text { with special uncooperative } \\
\text { needs. In-depth knowledge of } \\
\text { the technique, its risks, benefits } \\
\text { and monitoring of vital signs } \\
\text { must be obtained. }\end{array}$ \\
\hline $\begin{array}{l}\text { Salinas } \\
\text { Salme- } \\
\text { ron et } \\
\text { al. [17] }\end{array}$ & Korea & 138 & $\begin{array}{l}\text { Mental } \\
\text { Retardation, } \\
\text { Autism, } \\
\text { Brain Injury, } \\
\text { Dementia. }\end{array}$ & 40,5 & Propofol & $\begin{array}{c}\text { Intravenous } \\
\text { Sedation }\end{array}$ & $\begin{array}{c}\text { - 10.86\% received induction } \\
\text { with Sevoflurane } \\
\text { - 9.42\% received another } \\
\text { sedative. } \\
\text { - The initial dose of Propofol } \\
\text { was } 2-4 \mu \mathrm{g} / \mathrm{ml}(\mathrm{mental} \\
\text { retardation), } 2-5 \mu \mathrm{g} / \mathrm{ml} \\
\text { (autism), } 1-4.5 \mu \mathrm{g} / \mathrm{ml} \\
\text { (brain damage) and } 2-4 \mu \mathrm{g} / \\
\text { ml (dementia) } \\
\text { - The maintenance dose of } \\
\text { Propofol in all groups was } \\
2.8 \text { to } 3 \mu \mathrm{g} / \mathrm{ml} \text {. }\end{array}$ & $\begin{array}{l}\text { There were no complications, } \\
\text { deep sedation is a great alter- } \\
\text { native to dental treatments for } \\
\text { participants with intellectual } \\
\text { disabilities. }\end{array}$ \\
\hline
\end{tabular}

The search involved articles published from 2014 to 2019 and included research conducted in seven different countries, including: Brazil, Japan, the Netherlands, Turkey, Sweden, Argentina and Korea. The samples varied widely in size, from 25 to 507 participants, and the main medications used were: Midazolam, Propofol, Ketamine, Sevoflurane, Fentanyl and Nitrous Oxide. A summary of the characteristics of the studies can be found in Table 1 [10-17].

\section{Results of individual studies}

Matsuki et al. [10] evaluated 507 participants with cerebral palsy, mental retardation and mental disorder, where $67.3 \%$ of the participants were sedated with Midazolam-Propofol, $16.8 \%$ with Midazolam and 13.8 with Propofol. Intraoperative respiratory depression and reduction in SpO2 occurred in participants who received deep sedation. The factor that involved the choice of sedative agents for intravenous sedation were the reports of previous studies, however the final decision was made by the dental anaesthesiologist, based on the condition of the participant and the treatment plan. Therefore, there must be a consideration of the safety and comfort of the participant.

Alkan et al. submitted 214 participants with Down syndrome, Cornelia Lange syndrome, van der Knaap disease, fragile $\mathrm{X}$ syndrome, cerebral palsy, autism and Willians syndrome, sedation by Midazolam, Ketamine, Propofol, Sevoflurane, Fentanyl and Nitrous oxide, where 6.5 of the participants underwent minimal sedation, $35 \%$ moderate and $58.4 \%$ deep. $3.7 \%$ of the participants had nausea and vomiting and as a result of sedation, 2 participants developed bronchospasm. Therefore, sedation can be performed safely by choosing the appropriate medication and using methods that do not depress the participants' breathing or reflexes.

Sugimura et al. [11] performed in 25 participants with dementia, intravenous sedation, using Propofol, where intraoperative complications were $46.2 \%$ circulatory and $52.3 \%$ respiratory. Bradycardia occurred in $13.8 \%$ of participants and hypotension in $12.3 \%$. Other events, such as coughing and snoring, occurred in $41.5 \%$ and $16.9 \%$ respectively. Even so, he concluded that dental treatments can be performed without problems by the intravenous route, but, keeping the attention to the aspiration of liquids, obstruction of the airways and respiratory inhibition.

Morimoto et al [12] performed 43 participants with intellectual disabilities, autism, epilepsy, cerebral palsy, Down syndrome, hearing impairment and Cornelia Lange syndrome, intravenous sedation (IVS) and intravenous sedation with airway and suction tube (IVSAS), with Midazolam and Propofol. A cough reflex was observed in $44 \%$ of IVSAS and $81.8 \%$ of IVS. Regarding spontaneous movements, $28 \%$ in IVSAS and $72.2 \%$ in IVS. Regarding the quality of sedation, there was a lower incidence of these events and automatically a higher quality of sedation in IVSAS. In participants with moderate or severe disability, IVSAS sedation is considered to improve the safety of sedation during dental treatment. 
Rignell et al [13] evaluated 61 participants with major neurocognitive disorder, using Midazolam orally, where $44 \%$ of the participants did not experience cooperation problems when sedated, and $43 \%$ of the participants were treated with minor adaptations. Unfavourable side effects (drowsiness and hyperactivity) were rare. Thus, oral sedation with Midazolam, seems to be effective and safe in the dental treatments of people with major neurocognitive diseases.

Hermanus et al. performed intravenous sedation with Propofol in 124 participants with intellectual disabilities, where $18.5 \%$ of the participants were premedicated with Diazepam and 5.6\% with Oxazepam orally. Bradycardia occurred in 5, 6\% and tachycardia in $3.2 \%$ of cases. Hypertension occurred in $0.8 \%$ of the participants. Due to airway obstruction, chin elevation and $0.8 \%$ verbal stimulation were necessary in $1.6 \%$. Therefore, propofol sedation was effective and resulted in sufficient sedation levels, without complications and safely in the office, performed by sedation professionals with experience and training, both with Propofol and with participants with disabilities [14].

Ferrary et al, [15] performed 29 participants with Down Syndrome, oral sedation with Midazolam, where $71.4 \%$ of the participants used $15 \mathrm{mg}$ and obtained 4 and 5 on the score of the Houpt scale and $93.33 \%$ of the participants with $30 \mathrm{mg}$ of Midazolam and obtained on the score of the Houpt scale 5 and 6. Thus, there were no adverse effects among the participants and psychoprophylaxis combined with conscious oral sedation proved to be a good strategy for participants with Down syndrome to have a treatment quality dental care.

Picciani et al. [16] evaluated 26 participants with autism, intellectual disability and Down syndrome, who used oral sedation with Midazolam $7.5 \mathrm{mg}$ or $15 \mathrm{mg}$, where $83 \%$ of the sedation proved to be safe and effective. There was a significant reduction in systolic and diastolic blood pressure parameters in the intraoperative and postoperative periods, when compared to the preoperative period and a $6 \mathrm{bpm}$ reduction in heart rate on average. Therefore, benzodiazepine sedation is safe and effective for participants with uncooperative special needs. In-depth knowledge of the technique, its risks, benefits and monitoring of vital signs must be obtained.

Salinas et al. [17] performed in 138 participants with mental retardation, brain damage, dementia, intravenous sedation with Propofol, where $10.86 \%$ received sedation induction with Sevoflurane and $9.4 \%$ received another sedative. The initial dose

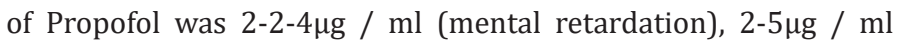

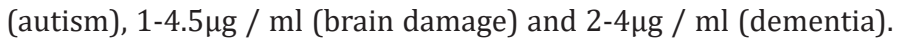
The maintenance dose of Propofol in all groups was 2.8 to $3 \mu \mathrm{g} /$ $\mathrm{ml}$. Thus, there were no complications, and deep sedation is a great alternative for dental treatments in participants with intellectual disabilities.

\section{Discussion}

Dental treatment for special need patients is a necessity. However, the inclusion of these patients is challenging, because in addition to the vast majority of them aversing dental treatment, there is still a difficulty in finding professionals able to provide assistance and who know how to deal with the complications associated with the medical condition of these patients $[10,11]$ Nevertheless, performing a viable, safe and effective treatment with practices that can be used to facilitate management, must be a reality and, a maneuver of great value is conscious sedation. Thus, in this integrative review, we will evaluate the types of sedation, with the technique and the drug chosen, to be used during dental treatment for patients with disabilities.

When we talk about patients with disabilities, undoubtedly the attitude of first choice is that of conditioning through psychological adequacy, however it is not always enough to make dental treatment possible. In this way, conscious sedation is a safe and effective option, allowing the patient to be more cooperative, establishing treatment as more invulnerable and traumatic [12]. The most used drugs for this purpose, in the articles of the present review, were Midazolam, Propofol [12-19].

Midazolam is a benzodiazepine imidazole, which is administered by several routes such as: Oral, intravenous, intranasal, intramuscular. Being used for sedation in several procedures in treatments that are surgical or not. It is efficient for depressing the central nervous system causing few adverse effects [20]. However, it is important to highlight that Midazolam, when administered alone, should be used in short-term procedures, with the patient always monitored [21] It is considered a highly effective drug in uncooperative patients, with neurocognitive disorders due to its quick start of action and convenience to intermediate the level of sedation necessary for the procedure [16]. As a quick start, Ferrary et al. [15] emphasized that Midazolam has sedative effects initiated in 30 minutes, they are anticonvulsant, muscle relaxant, anxiolytics and hypnotics with a wide safety margin between toxic dose and therapy [18]. In intravenous sedation, in dental procedures, propofol is one of the most widely used drugs. Due to its rapid power to induce sedation (30 to 45 seconds) and recovery with fewer adverse reactions [19,22]. In addition, the application of Propofol alone or combined with a premedication and use of analgesics, can be beneficial to bring safety to the sedated patient in addition to avoiding pain and hyperalgesia, in the postoperative period [17]. It is noteworth that Propofol has its dose-dependent adverse effects, such as hypotension and respiratory depression [23]. And to be administered it is essential to follow up an anaesthesiologist.

In conscious sedation for patients with special needs, we can also use Nitrous Oxide, a gas that besides having analgesic functions, has sedative capacity, reducing the sensitivity to pain, bringing tranquillity to the procedure safely [24]. Nitrous oxide, is supplied together with oxygen, through nasal masks. However, due to the deficiency, breathing difficulties through nasal mask and verbal contact often occur, making communication difficult [25]. For this reason, it is often not the most used form of sedation when we talk about patients with disabilities, but when administered in combination with other medications, such as Midazolam, orally, it 
usually ends up being well accepted by patients [16]

It is worth mentioning that regardless of the chosen form of sedation, some precautions must be performed pre-sedation. First, a good anamnesis with a medical history, treatments already performed in hospitals, routine medications for health problems and their habits must be performed. The second stage includes the preoperative evaluation of the patient with clinical evaluation, request for the necessary laboratory tests, delivery of the consent form and pre, intra and postoperative instructions to the patient, in writing, highlighting the fasting of liquids and solids, for four hours before the procedure. In addition, it is important to assess the patient's vital signs such as blood pressure and respiratory rate. The patient must always come with a companion, as he / she will receive in writing and verbally, from the dentist, all post-operative guidance and care $[2,26]$

Although safe, the use of these medications requires the monitoring of patients' vital signs. The health professional has the responsibility to make this monitoring possible, while the patient is in the process of sedation. It can be performed directly, or through monitors, which show respiratory and cardiovascular vital signs. There is also the possibility of controlling the patient's oxygen saturation using pulse oximeters. Which are nothing more than, meters of oxygen being transported by haemoglobins in arterial blood and are expressed as a percentage. But in order to monitor respiratory ventilation better and in real time, capnography can be used (which makes an analysis of carbon dioxide through an infrared gas in exhaled air, offering an absolute value of dioxide) and the pre-tracheal stethoscope [27]. The American Society of Anaesthesiologists, requests that when there is moderate and deep sedation, there must be monitoring of carbon dioxide, and an observation of clinical signs [28].

However, in Brazil, according to the Federal Council of Medicine, through Resolution 1.670 / 03, it imposes that deep sedation should only be performed by anaesthesiologists and in environments providing safe conditions to be performed, leaving the patient's care to the doctor who is not performing the procedure, which requires sedation. However, on conscious sedation, the Federal Council of Dentistry (CFO), in resolution 51/04, taking into account Law No. 5081, of August 24, 1966, regulating the exercise of the dental profession, in its article 6, item VI, indicates that the dental surgeon can apply analgesia (conscious sedation) with Nitrous Oxide, as long as it is proven to be effective and when the use conceives the effective means for the treatment. For this reason, the work of a multitask team is significantly important, in which the patient can be monitored by another professional in addition to the one who is performing the procedure, safely, but not always feasible in a dental office.

A multiprofessional relationship between patient, family, dentist, doctor, speech therapist, occupational therapist is of extremely importance for the agreement of the real needs of patients and the correct indication of sedation [29]. In this way, we ensure that new tactics and options to control cooperation problems, which appear in various ways, among different patients, according to the severity of the disease and their age, have been tested. And, although we know that the collaboration of patients, regardless of the disability, is a crucial point to indicate sedation, we often use it only for the comfort of the patient, so that the procedures do not become synonymous with suffering, bringing trauma and future impossibilities of provision of oral health.

\section{Conclusion}

It is necessary to adequacy of the dentist in relation to each patient with their own disability, their limitations and needs of facilitators so that there is the feasibility of the dental procedure. Starting in search of a non-pharmacological cooperation but remembering that it can be used by sedative agents and their techniques, not only to enable the treatment completely, but so that the patient is comfortable, without suffering and without major emotional damage, in his daily dental routine.

\section{Acknowledgement}

The authors declare no potential conflict of interest with respect to the authorship and/or publication of this article.

\section{References}

1. Vainio L, Krause M, Inglehart MR (2011) Patients with special needs: dental students' educational experiences, attitudes, and behavior. J Dent Educ 75(1): 13-22.

2. Munhoz EA, Polli VA, Sordi MB, Lisboa ML, Camargo AR (2016) Dental management of special needs patients: a literature review. Glob J Oral Sci 2(1): 33-45.

3. Yang BW, Waters PM (2019) Conscious sedation and reduction of fractures in the paediatric population: An orthopaedic perspective. J Child Orthop 13(3): 330-333.

4. Mason KP (2015) Pediatric sedation outside of the operating room: A multispecialty international collaboration. $\left(2^{\text {nd }}\right.$ edn).

5. Silva CC, Lavado C, Areias C, Mourão J, Andrade D de (2015) Conscious sedation vs general anesthesia in pediatric dentistry-a review. Med Express 2(1).

6. Drysdale D (2015) The use of intranasal midazolam in a special care dentistry department: technique and cases. Prim Dent J 4(2): 42-48.

7. Chávez EM, Wong LM, Subar P, Young DA, Wong A (2018) Dental care for geriatric and special needs populations. Dent Clin North Am 62(2): 245-267.

8. Attri J, Sharan R, Makkar V, Gupta K, Khetarpal R, et al. (2017) Conscious sedation: Emerging trends in pediatric dentistry. Anesth Essays Res 11(2): 277-281.

9. Sacoor S (2017) Anaesthesia and sedation for the autistic patient. SAAD Dig 33: 40-43.

10. Matsuki Y, Okamura T, Shiozaki K, Matsuura N, Kasahara M, Ichinohe T (2014) Survey on choice of intravenous sedative agent at department of dental anesthesiology, Tokyo Dental College Chiba Hospital between 2010 and 2011. Bull Tokyo Dent Coll 55(3): 157-162.

11. Sugimura M, Kudo C, Hanamoto H, Oyamaguchi A, Morimoto Y, et al. (2015) Considerations during intravenous sedation in geriatric dental patients with dementia. Clin Oral Investig 19(5): 1107-1114. 
12. Morimoto Y, Hayashi M, Yokoe C, Kinugawa T, Iida T, et al. (2017) Intravenous sedation for dental treatment in patients with intellectual disability-efficacy of nasal airway, pharyngeal suction tube and oxygen tube placement. Biomed Res 28(11): 4931-4936.

13. Rignell L, Mikati M, Wertsén M, Hägglin C (2017) Sedation with orally administered midazolam in elderly dental patients with major neurocognitive disorder. Gerodontology 34(3): 299-305.

14. Vaessen HHB, Schouten ANJ, van der Hoeve H, Knape JTA (2017) The feasibility of office-based propofol sedation for dental care in patients with intellectual disability by sedation practitioners. Spec Care Dent 37(2): 93-98.

15. Ferrary T, Sanchez Ratto N, Martinez D, Alvarez M, Bianchi ML, et al. (2019) Psychoprophylaxis for oral conscious sedation for dental care in Down syndrome adults with behavioral disorder. Spec Care Dent 39(4): 389-398.

16. Picciani BLS, dos Santos BM, Silva Júnior GO, Marinho MA, Papa EG, et al. (2019) Contribution of benzodiazepines in dental care of patients with special needs. J Clin Exp Dent 11(12): e1170-e1174.

17. Salinas Salmeron KS, Kim HJ, Seo KS (2019) Effects site concentrations of propofol using target-controlled infusion in dental treatment under deep sedation among different intellectual disability types. J Dent Anesth Pain Med 19(4): 217-226.

18. Nelson LP, Getzin A, Graham D, Zhou J, Wagle EM, et al. (2011) Unmet dental needs and barriers to care for children with significant special health care needs. Pediatr Dent 33(1): 29-36.

19. Delli K, Reichart PA, Bornstein MM, Livas C (2013) Management of children with autism spectrum disorder in the dental setting: Concerns, behavioural approaches and recommendations. Med Oral Patol Oral Cir Bucal 18(6): e862-868.

20. Conway A, Rolley J, Sutherland JR (2016) Midazolam for sedation before procedures. Cochrane Database Syst Rev 2016(5): CD009491.
21. Rodrigues A, Lima DA (2003) A randomized, controlled, crossover trial of oral midazolam and hydroxyzine for pediatric dental sedation Sedação com midazolam e hidroxizina por via oral em. Pesqui Odontol Bras 17(3): 206-211.

22. Yokoe C, Hanamoto H, Sugimura M, Morimoto Y, Kudo C, et al. (2015) A prospective, randomized controlled trial of conscious sedation using propofol combined with inhaled nitrous oxide for dental treatment. J Oral Maxillofac Surg 73(3): 402-409.

23. Ahmed SS, Hicks SR, Slaven JE, Nitu ME (2016) Deep sedation for pediatric dental procedures: Is this a safe and effective option? J Clin Pediatr Dent 40(2): 156-160.

24. Zanelli ME, Ricci Volpato LE, Ortega AL, Borges AH, Fábio Aranha AM (2015) Nitrous oxide for dental treatment in patients with infantile autism: a literature review. RSBO Rev Sul-Brasileira Odontol 12(2): 202208.

25. Galeotti A, Garret Bernardin A, D Antò V, Ferrazzano GF, Gentile T, et al. (2016) Inhalation conscious sedation with nitrous oxide and oxygen as alternative to general anesthesia in precooperative, fearful, and disabled pediatric dental patients: A large survey on 688 working sessions. Biomed Res Int 2016: 7289310.

26. ADA (2009) Guidelines for the use sedation and general anesthesia by dentists. pp. 1-12.

27. Bennett JD, Kramer KJ, Bosack RC (2015) How safe is deep sedation or general anesthesia while providing dental care? J Am Dent Assoc 146(9): 705-708.

28. Southerland JH, Brown LR (2016) Conscious intravenous sedation in dentistry: a review of current therapy. Dent Clin North Am 60(2): 309346.

29. Norderyd J, Lillvist A, Klingberg G, Faulks D, Granlund M (2015) Oral health, medical diagnoses, and functioning profiles in children with disabilities receiving paediatric specialist dental care-a study using the ICF-CY. Disabil Rehabil 37(16): 1431-1438. 